\title{
DOES THE ALTITUDE AFFECT THE STABILITY OF MONTANE FORESTS? A STUDY IN THE KAHUZI-BIEGA NATIONAL PARK (DEMOCRATIC REPUBLIC OF THE CONGO)
}

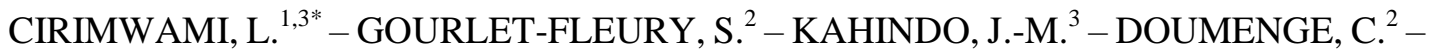 \\ GONMADJE, C. $^{4}-$ AMANI, C. ${ }^{5}$ \\ ${ }^{1}$ Université du Cinquantenaire, Faculté de Sciences \\ Lwiro, Sud-Kivu, République Démocratique du Congo \\ ${ }^{2}$ CIRAD, UR Forêts et Sociétés, Campus International de Baillargue \\ TA-C-105/D, F-34398 cedex 5 Montpellier, France \\ ${ }^{3}$ Université de Kisangani, Faculté des Sciences \\ PO. Box. 2012, Kisangani, République Démocratique du Congo \\ ${ }^{4}$ University of Yaounde I, Plant Biology \\ PO. Box.812, Yaounde, Cameroon \\ ${ }^{5}$ Center for International Forestry Research (CIFOR) \\ Kisangani, Democratic Republic of the Congo \\ *Corresponding author \\ e-mail: legrand.cirimwami@unikis.ac.cd \\ (Received $21^{\text {st }}$ Aug 2017; accepted $7^{\text {th }}$ Oct 2017)
}

\begin{abstract}
To understand the functioning of montane forests, this study was conducted in the highlands of the Kahuzi-Biega National Park in the Democratic Republic of the Congo. The relationship between the altitude and the floristic stability of woody layers and regeneration capability of canopy species after many years of disturbance was studied. Ten 1-ha plots were established from $1935 \mathrm{~m}$ to $2760 \mathrm{~m}$ a.s.l. In each plot we inventoried the trees $\geq 10 \mathrm{~cm}$ of diameter at breast height (DBH), separating a canopy layer ( $10 \%$ of the tallest trees) and an understorey layer (all the other trees). In each plot, we nested a 0.1 ha subplot to inventory the saplings between 1 and $10 \mathrm{~cm}$ DBH. We found that the Jaccard index of dissimilarity between the understorey layer and the canopy layer decreases with the altitude. The proportion of species which are well represented in the three layers increases with the altitude. The number of pioneer species decreases with the altitude while that of non-pioneer and shade tolerant species increases. These findings suggest that altitude influences the stability of highland forests, higher altitude being more stable than lower ones in the case of this study.
\end{abstract}

Keywords: highland forests, regeneration capability, woody layers, Jaccard index of dissimilarity, nonpioneer species

\section{Introduction}

Montane forests are biodiversity-hotspots and are among the most species-rich ecosystems worldwide (Bussmann, 2001a, 2001b). They are also particularly rich in uncommon and endemic species (Plumptre et al., 2006; Skarbek, 2008). Their high diversity is due to a great variety of environmental conditions (Clinebell et al., 1995; Richter et al., 2009) as well as persistence of favorable climatic conditions during past geological times, which has allowed the survival of numerous plant species (Dimitrov et al., 2012). They are nevertheless one of the most fragile ecosystems (Sharma et al., 2009) and one of the most vulnerable to global change (Lenoir, 2009). Their 
vulnerability is due to the fact that they cover rather small areas at the Earth's scale and that they are governed by specific environmental conditions (geomorphological factors, soil, cloudiness, humidity, temperature,...) which may rapidly change under climate warming and human pressure (Fjeldså and Lovett, 1997; Körner, 2009; Skarbek, 2008; Nzigidahera, 2012).

In tropical forests, numerous studies on montane forests have focused on the relationship between altitude and structure, or between altitude and floristic composition (Hedberg, 1951; Jamir et al., 2006; Hemp, 2006). Several studies have shown that lower altitudes are home to taller trees than higher altitudes (Ashton and Hall, 1992; Siebert, 2005; Richter et al., 2009), even in small elevation gradients (Gonmadje et al., 2017). In the same way the lower altitude forests differ from the higher ones in their floristic composition (Schmitt et al., 2010; Gonmadje, 2012; Admassu et al., 2016; Imani et al., 2016), with a decrease of species diversity with increasing altitude (Doumenge, 1998; Lomolino, 2001; Tassin et al., 2004; Hemp, 2006; Mangambu et al., 2013; Mwanga Mwanga et al., 2014; Admassu et al., 2016; Imani et al., 2016), even if not systematically (Siebert, 2005; Delnatte, 2010; McCain and Grytnes, 2010; SalasMorales and Meave, 2012).

Some studies in the montane forests focused on their dynamic patterns through space and time (Fine et al., 2005; Zhang and Zhang, 2007; Njunge and Mugo, 2011). However, the study of vegetation dynamics requires observations through relatively long time scales. When such observations are unavailable, a comparison of the floristic composition between forest layers - canopy, understorey, sapling layers - can lead to some interesting results on the possible dynamics between these layers (Kalacska et al., 2004; Schulze et al., 2005; Behera and Misra, 2006). This approach is simple when it is used for forests dominated by one species and becomes more complex in forests with many species and a diversified canopy (Woods and Whittaker, 1981). Taking into account both the abundance and the occurrence of species in the considered forest layers can spread some light on the vegetation dynamics (Hall and Swaine, 1976; McEwan et al., 2005; Amani and Lejoly, 2014). Such studies were performed in various lowland forests (Letouzey, 1957; Woods and Whittaker, 1981; Swaine and Hall, 1988; Connell and Lowman, 1989) but in a limited number of highland forests (Njunge and Mugo, 2011; Shiels and Walker, 2013).

Based on the abundance patterns of species within different layers, Pivellon and Coutinho (1996) distinguished "stationary" stable forests and "transient" unstable forests or changing forests. Stable forests are those in which floristic composition of the canopy layer does not differ significantly from that of the lower forest layers. Connell and Lowman (1989) also defined stable forests as those characterized by one or more similar dominant species in the canopy and lower layers (meaning that these species will likely dominate the canopy in next generations) whereas unstable forests are considered to be characterized by one or more species which are currently dominant in the canopy but become scarce in lower layers. From a floristic dynamics point of view, it is expected that tree species characterizing the current canopy will die and eventually be replaced by the species found in the current sapling and understorey layers which are able to reach the canopy (Hallé et al., 1978; Woods and Whittaker, 1981; Nicotra et al., 1999).

It is generally agreed that young forests tend to have more canopy species with few - if any - regeneration in the sapling and understorey layers while old growth and stable forests are mainly dominated by canopy species with abundant regeneration in the sapling and understorey layers. In other words, forests which have experienced some disturbance 
are expected to incorporate in their canopy a higher proportion of poorly regenerating pioneer species than old growth forests (Connell and Lowman, 1989; Pivellon and Coutinho, 1996; Vandermeer and Granzow de la Cerda, 2004; Yang et al., 2008).

In a case of non-disturbance or equal disturbance between lower and higher altitudes, lower altitudes develop more stable forests than higher ones. Due to the sensibility of higher altitudes to global change, they are liable for instability (Pierlot, 1966; Njunge and Mugo, 2011). These forests thus tend to be dominated by many pioneer species (e.g. forests at higher altitudes in general, Pierlot, 1966) and could be more instable (Wood and Whittaker, 1981) compared to forests at lower altitudes, but this general trend is reversed in a case of unequal disturbance history between lower and higher altitudes (Runge, 2007).

The forest ecosystems in the highlands of the Kahuzi Biega National Park (KBNP) are spanning from 1800 to $3315 \mathrm{~m}$ of altitude. Some of them have been severely disturbed as a consequence of recurrent political turmoil (and its subsequent wars and various armed conflicts) in the Democratic Republic of the Congo (DRC) and neighboring countries (World Heritage, 2005; Jepson et al., 2015). Though some studies reported the consequences of these anthropogenic pressures on the vegetation of the KBNP (Masumbuko, 2011; Kabonyi et al., 2011), very few is known regarding the regeneration and restoration capabilities of its forest ecosystems, more particularly in its highland areas. The role of altitude in the restoration processes has also been poorly studied (Gonzalez et al., 2013; Njunge and Mugo, 2011) while the lack of such information for the KBNP highland's forests is detrimental to the evaluation of their sensitivity to global change and the development of a sustainable management strategy (Dupuy, 1998; Dupuy et al., 1998). In the KBNP, it can be assumed that these political conflicts disturbed more the lower altitudes than higher altitudes as it is easier to make camping or logging activities in lower altitudes than going far at mountain's summits in higher altitudes (Magrath et al., 2007)

Here we investigated the stability state of these highlands forests with respect to disturbance history and in relation with the altitude. We evaluated the dynamic trends of these montane forests by testing if 1) the dissimilarity between the canopy layer and understorey layer decreases with the altitude; 2) the most abundant canopy species remain abundant in lower layers at higher altitudes; 3 ) the proportion of pioneer species decreases with the altitude and that of non-pioneer species increases with the altitude in the three layers.

\section{Material and methods}

\section{Study area}

The study was conducted in the Kahuzi Biega National Park (KBNP) which is located in the eastern part of the DRC, between $28.45^{\circ} \mathrm{E}-28.85^{\circ} \mathrm{E}$ of longitude and $2.66^{\circ} \mathrm{S}-2.09^{\circ} \mathrm{S}$ of latitude. The KBNP harbours three main vegetation types according to the altitude, including lowland forests (stretching from $700 \mathrm{~m}$ to $1250 \mathrm{~m}$ a.s.l), submontane forests (from $1250 \mathrm{~m}$ to $1800 \mathrm{~m}$ ) and highland forests from $1800 \mathrm{~m}$ to 3315 m a.s.l (Fischer, 1993; Mangambu, 2013). This study covers only the highland forests (Fig. 1).

The KBNP is established in two main climatic zones. The lowland areas undergoes an equatorial climate where it rains almost throughout the year. Precipitations are high and can reach more than $2600 \mathrm{~mm}$; temperature varies between 15 and $25^{\circ} \mathrm{C}$. In the 
highland areas and submontane forests, the climate is characterized by 3 to 4 months of dry season and lower rainfall (mean: $1900 \mathrm{~mm}$; Fischer, 1993). The highlands are dominated by hills and marshes. They are located in the Albertine rift, a biodiversity hotspot (Plumptre et al., 2006, Poulsen et al., 2005). In terms of phytogeography, the highlands are part of the afromontane center of endemism but the lowlands belong to the guineo-congolese center of endemism (White, 1983).

The highlands of the KBNP are dominated by a vegetation which is structured in 3 main strata including arborescent strata, understorey strata and herbaceous strata. This forest has many epiphytes especially lichens, ferns and many Orchidaceae species. The arborescent strata is characterized by species such as Albizia adianthifolia, Neoboutonia macrocalyx, Dombeya torrida, Macaranga capensis, Polyscias fulva, Alangium chinense, Shirakiopsis elliptica, Pleiocarpa pycnantha, Syzygium guineense, Symphonia globulifera, Tabernaemontana stapfiana, Carapa grandiflora, Nuxia floribunda, Lachnopylis thomensis, Agauria salicifolia, Morella salicifolia, Podocarpus milanjianus, Afrocarpus usambarensis... The understorey strata is constituted by Hagenia abyssinica, Maesa lanceolata, Galiniera saxifraga, Psychotria mahonnii, Rapanea melanophloeos, Cyathea manniana, Erica arborea, Alchornea hirtella, Chassalia subbochreata... In the herbaceous strata we can see species like Sinarundinaria alpina, Lobelia gibberoa, Salacia sp, Urera hypselodendron, Pilea sp, Ipomoea involucrata, Scadoxus multiflorus, Hypoestes trifolia, Sericostachys scandens, Centella asiatica, Ageratum conyzoides, Aspilia kotschyii, Helichrysum spp, Microglossa pyrifolia, Mikania spp, Senecio spp, Vernonia spp, Impatiens spp, Begonia spp, Cuscuta kilimanjari... and many ferns.

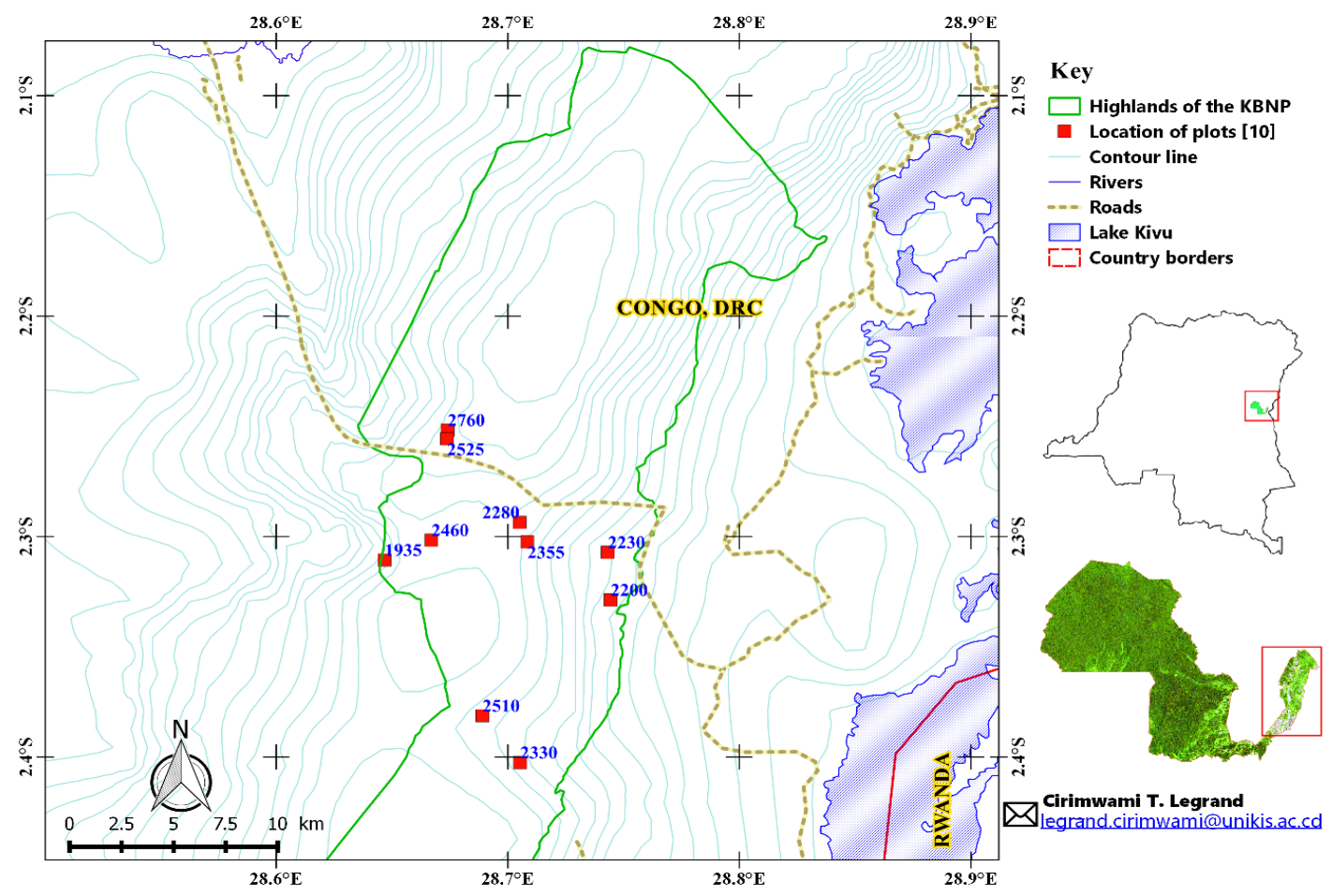

Figure 1. Location of the ten studied plots in the highlands of the Kahuzi-Biega National Park in the Democratic Republic of the Congo. 


\section{Data collection}

A total of 10 1-ha $(200 \mathrm{~m} \times 50 \mathrm{~m})$ nested plots (displaying the canopy layer, the understorey layer and the sapling layer) were established between 1935 and $2760 \mathrm{~m}$ a.s.l. As there are many conflicting statements on the minimum height of canopy species in montane forests (Lebrun and Gilbert, 1954; De Barcellos Falkenberg et al., 1995), we arbitrary considered the $10 \%$ tallest trees of the stand as belonging to the canopy layer, the remaining trees belonging to the understorey layer. Trees of the canopy and the understorey layers and reaching at least $10 \mathrm{~cm}$ of diameter at breast height $(\mathrm{DBH})$, were inventoried within $(1 \mathrm{ha})$ plots. For this category of trees, height and diameter were measured, respectively by a Laser Ace and a DBH-meter. The height varied from 2 to $28 \mathrm{~m}$ while the diameter varied from 10 to $155 \mathrm{~cm}$. Inside each 1-ha plot, the sapling layer (comprising all woody species between $1 \mathrm{~cm}$ and $10 \mathrm{~cm}$ of DBH) was inventoried within 0.1 ha $(200 \mathrm{~m} \times 5 \mathrm{~m})$ subplots. The altitude was recorded using an altimeter SUUNTO Vector $( \pm 5 \mathrm{~m})$ while the geographic coordinates were recorded with a Garmin GPS ( $\pm 3 \mathrm{~m}$ of precision).

\section{Species identification}

Most species were directly determined in the field. The remaining species were later identified at the Herbarium of the Lwiro research center, by comparing collected plant samples and using existing floras (Troupin and Bridson, 1982; Fischer and Killmann, 2008) and to the online flouring plant database of Geneva (African Plant Database, Lebrun and Stork, 1991-2015). We identified $87.6 \%$ of all species till to the level of species, $9.3 \%$ to the level of genera and $3.1 \%$ of all species were not identified. We used the nomenclature proposed by the Angiosperm Phylogeny Group (APG IV) in 2016 (Chase et al., 2016).

\section{Data analysis}

\section{Species richness and diversity indices}

In each plot and for the canopy and understorey layers, species richness was estimated using the rarefaction index (r) while diversity was calculated by the Fisher alpha index $(\alpha)$. The rarefaction index $(E q .1)$ for species richness estimations represents the expected number of species in a sample of $n$ individuals selected at random from a collection containing $\mathrm{N}$ individuals, $\mathrm{S}$ species and $\mathrm{N}_{\mathrm{i}}$ individuals in the $\mathrm{i}^{\text {th }}$ species (Hurlbert, 1971). If a random sample of $\mathrm{n}$ individuals is taken from each community, the number of species recorded increases with the number of individuals sampled (Bell, 2000), that is why it is better to analyse the species richness with standardized number of individuals within plots. This index is:

$$
\mathrm{r}=\mathrm{E}\left(\mathrm{S}_{\mathrm{n}}\right)=\Sigma_{1}\left[1-\frac{\left(\begin{array}{c}
\mathrm{N}-\mathrm{N}_{\mathrm{n}} \\
\mathrm{n}
\end{array}\right)}{\left(\begin{array}{l}
\mathrm{N} \\
\mathrm{n}
\end{array}\right)}\right]
$$

The Fisher alpha index was calculated from the formula proposed by Fisher et al. (1943). This index is mostly influenced by rarer species (Magurran, 2004) and estimates the number $\mathrm{S}$ of species with $\mathrm{N}$ observed individuals (Fisher et al., 1943; Magurran, 2004), it is frequently used in forest related studies (Gonmadje et al., 2011, GourletFleury et al., 2013). We used this index as it considers the whole individuals sampled in 
each plot without any standardization of individuals as it is in the previous index, it calculates the diversity.

\section{Variation of woody layers floristic dissimilarity along the altitudinal gradient}

We compared the floristic compositions of the two layers (canopy and understorey) within the established 10 plots. The Jaccard index of dissimilarity was calculated between each pair of plots situated at the same altitude one belonging to the understorey and another to the canopy. This allowed to quantify the variation in floristic composition of communities at each altitude (Jaccard, 1908; Legendre et al., 2005; Tuomisto and Ruokolainen, 2006). We then made the correlation between this dissimilarity index and the altitude to assess the way the altitude and related factors can influence the floristic stability in this area).

\section{Correlation between "well represented species" and the altitude}

The distribution of canopy species into the canopy layer, understorey layer and sapling layer were performed. We calculated the relative abundance of each species in the three layers plot by plot and compared those three values using a $\mathrm{Chi}^{2}$ test to test if those relative abundances show any statistical difference or not. If the difference is significant, the distribution of the considered species is not equilibrated in the three layers. If the difference is not significant, it means that the relative abundance of the species in the canopy is not different statistically from its relative abundance in the understorey and sapling. These species are considered as well represented species in the three layers. We then made a correlation of the proportion of well represented species and the altitude to test if higher altitudes have more "well represented species" than lower altitudes.

\section{Light requirement of species in the three layers}

The light requirement (LR) of species informs on the degree of disturbance in a forest (Hawthorne, 1996; Van Gemerden et al., 2003a). The LR of each species was found in the literature especially in Lebrun and Gilbert (1954), Pierlot (1966), Lovett et al. (2006) and in the database developed by Bénédet et al. (2016). Three categories were considered: Pioneer species, Non-Pioneer Light Demanding species and Shade tolerant species. Species for which we didn't find their LR were categorized as "Unclassified". In each layer we calculated the proportion $(E q .2)$ of individuals belonging to each LR category:

$$
\mathrm{PX}_{\mathrm{A}}=\frac{\text { Individuals of } \mathrm{X}_{\mathrm{A}}}{\mathrm{N}_{\mathrm{A}}} \times 100
$$

Where $\mathrm{PX}_{\mathrm{A}}$ is the proportion of individuals belonging to $\mathrm{X}$ light requirement category present in the plot $\mathrm{A}$ and $\mathrm{N}_{\mathrm{A}}$ the total number of individuals in the plot $\mathrm{A}$. The number of individuals belonging to each LR were correlated with the altitude layer by layer.

For correlations, the Pearson method were used as our data required a parametric option. For regressions, we used linear models. All statistical analyses were performed with R software (R Development Core Team, 2015) using the vegan (Oksanen, 2017) and ecodist package (Goslee and Urban, 2007). 


\section{Results}

\section{Richness, diversity, and their relationship with altitude}

\section{General characteristics of the stands}

We inventoried a total of 7590 individuals: 1940 in the sapling layer $(194 \pm 58.6$ per 0.1 ha subplot), 5087 in the understorey layer (508.7 \pm 176.8 per 1 ha plot) and 563 in the canopy layer $(56.3 \pm 19.8$ per 1 ha plot $)$. A total of 62 species $(17.6 \pm 3.75$ per 0.1 ha subplot) belonging to 34 families were collected in the sapling layer, 82 species $(22.7 \pm$ 9.04 per 1 ha plot) belonging to 37 families in the understorey layer whereas in the canopy layer 45 species (10.8 \pm 2 per 1 ha plot) belonging to 29 families were collected.

In term of number of individuals, the most abundant families are the Rubiaceae followed by the Monimiaceae in the sapling layer, the Euphorbiaceae followed by the Rubiaceae in the understorey layer and the Euphorbiaceae followed by the Myrsinaceae in the canopy layer. The richest families are the Rubiaceae (10 and 16 species) in the sapling and understorey layers and the Euphorbiaceae (5 species) in the canopy layer. One of the 62 species of the sapling layer was only identified at the family level (Rubiaceae) and was represented by 3 individuals at $2355 \mathrm{~m}$ a.s.l. Three of the 82 species of the understorey were only determined at the family level (Rubiaceae). The three species were represented by only one individual and were collected at $1935 \mathrm{~m}$ a.s.l.

The relationship between numbers of individuals, numbers of species, Fisher-Alpha index of diversity, rarefaction index of richness and altitude are represented below (Fig. 2 and Table 1).
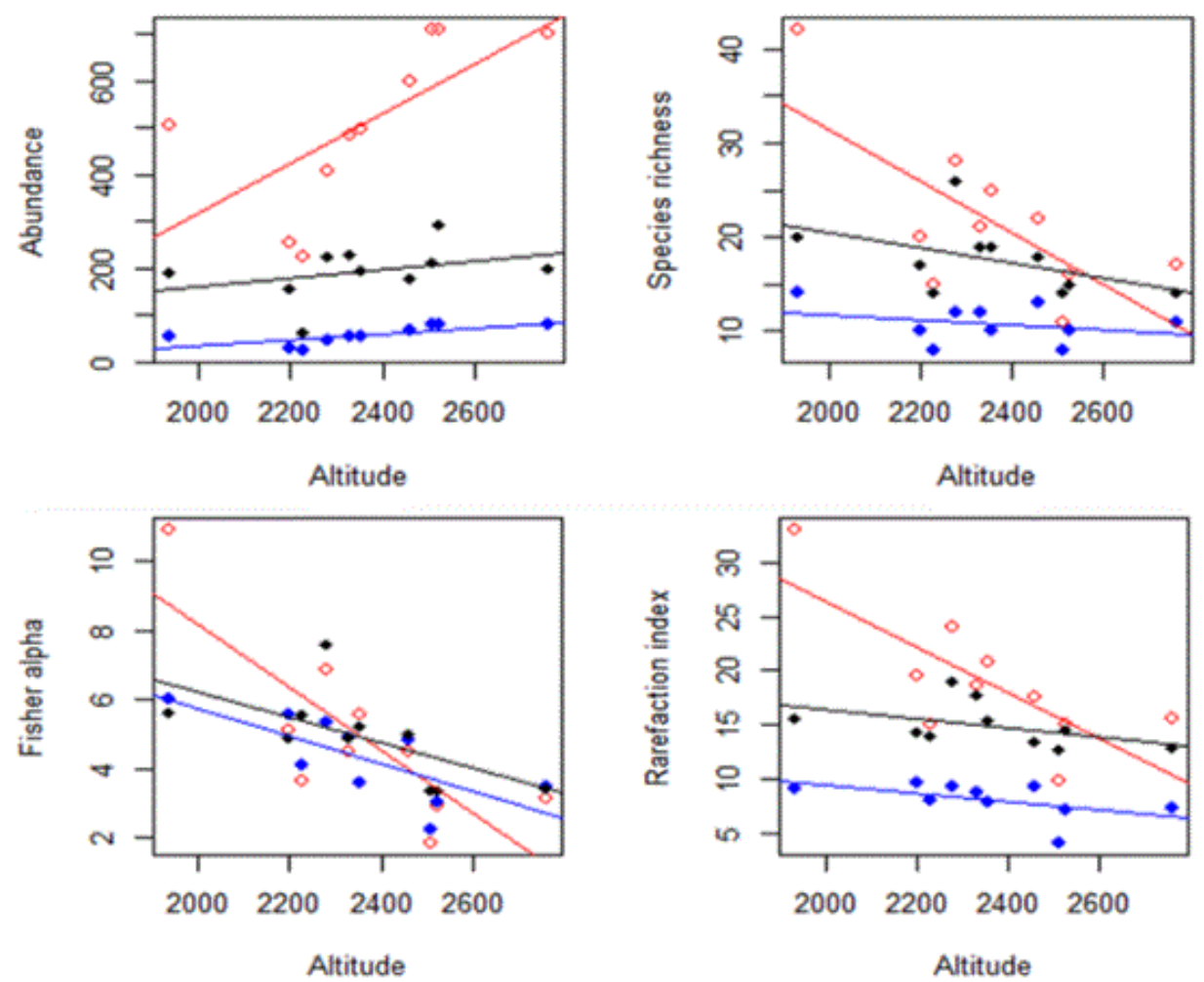

Figure 2. Relationship between number of individuals, species richness, Fisher-Alpha index, Rarefaction index and altitude in the three layers. The sapling layer is represented by the black line, the understorey by the red line and the canopy by the blue line. 
Within the three layers, the number of individuals increases with altitude, significantly for the understorey and the canopy (Fig. 2) while the species richness, the Fisher-Alpha index and the rarefaction index decrease with the altitude, but not significantly in most cases.

Table 1. Correlations between number of individuals, number of species, index of rarefaction, index of Fisher-Alpha and altitude in the three layers. " $r$ " is the coefficient of correlation of Pearson, $R^{2}$ the coefficient of determination and bold p-values show significant correlations at $\alpha=0.05$. The sapling layer was inventoried in 0.1 ha plots.

\begin{tabular}{|l|l|c|c|c|}
\hline \multicolumn{1}{|c|}{ Layer } & \multicolumn{1}{|c|}{ Variables } & r & $\mathbf{R}^{2}$ & p-value \\
\hline \multirow{4}{*}{ UNDERSTOREY } & Individuals/Altitude & 0.67 & 0.45 & $\mathbf{0 . 0 3 4}$ \\
\cline { 2 - 5 } & Species/Altitude & -0.71 & 0.5 & $\mathbf{0 . 0 2 2}$ \\
\cline { 2 - 5 } & Rarefaction/Altitude & -0.75 & 0.56 & $\mathbf{0 . 0 1 2}$ \\
\cline { 2 - 5 } & Fisher-Alpha/Altitude & -0.78 & 0.64 & $\mathbf{0 . 0 0 6}$ \\
\hline \multirow{5}{*}{ CANOPY } & Individuals/Altitude & 0.67 & 0.44 & $\mathbf{0 . 0 3 5}$ \\
\cline { 2 - 5 } & Species/Altitude & -0.31 & 0.1 & 0.38 \\
\cline { 2 - 5 } & Rarefaction/Altitude & -0.52 & 0.27 & 0.12 \\
\cline { 2 - 5 } & Fisher-Alpha/Altitude & -0.73 & 0.53 & $\mathbf{0 . 0 2}$ \\
\hline \multirow{5}{*}{ SAPLING } & Individuals/Altitude & 0.34 & 0.11 & 0.34 \\
\cline { 2 - 5 } & Species/Altitude & -0.47 & 0.22 & 0.17 \\
\cline { 2 - 5 } & Rarefaction/Altitude & -0.45 & 0.2 & 0.19 \\
\cline { 2 - 5 } & Fisher-Alpha/Altitude & -0.64 & 0.41 & $\mathbf{0 . 0 4 8}$ \\
\hline
\end{tabular}

\section{Relationship between floristic dissimilarity and altitude}

The dissimilarity between the understorey and the canopy layer of each plot were calculated according to the altitude (Fig. 3), to study whether the floristic stability of this ecosystem is correlated to the altitude.

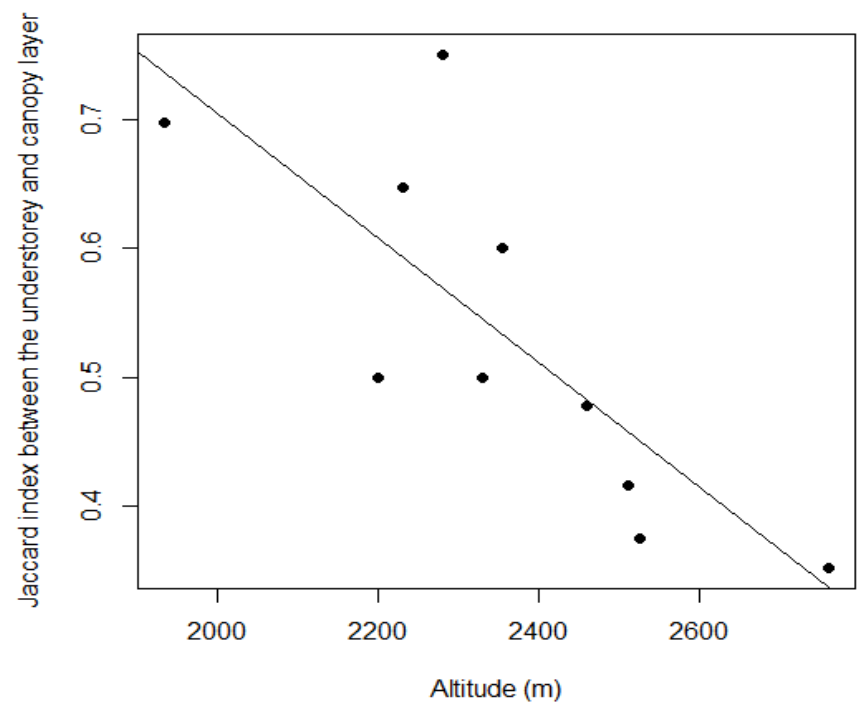

Figure 3. Correlation between the floristic dissimilarity (Jaccard index) between the understorey and the canopy layers and the altitude. 
The Jaccard index of dissimilarity significantly decreases with altitude $(\mathrm{r}=-0.79, \mathrm{p}$ $=0.006)$. This decrease confirms a more homogeneous floristic composition between the understorey and canopy layers when the altitude increases. Homogeneous floristic composition between the understorey and the canopy layer is a sign of floristic stability as this means that the species which are present in the canopy layer at higher altitude are also well represented in the understorey layer.

\section{Floristic and functional composition of the three layers and their relationship with altitude}

Distribution of the canopy species into the three layers

In the Figure 4, the percent of canopy species for which the proportion of their relative abundance (RA) in the three layers do not differ statically are presented. The relative abundances of canopy species in the canopy, the understorey and the sapling layers were computed and compared through a Chi ${ }^{2}$ test (see appendix for more details).

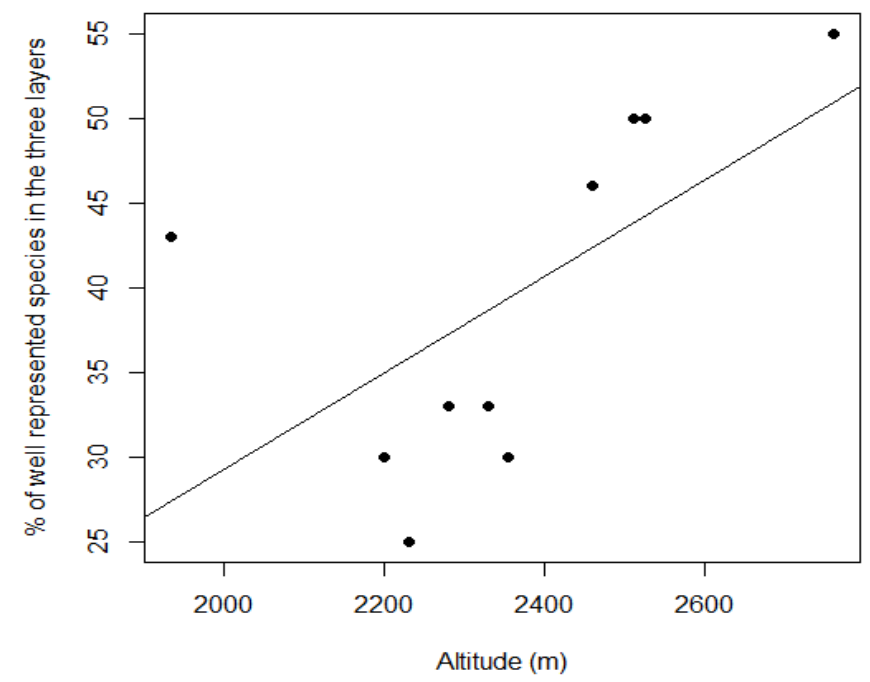

Figure 4. Correlation between the percent of well represented species and the altitude. Well represented species are those for which their relative abundance in the three layers do not differ significantly.

As shown in the Figure 4, the percent of well represented species in the three layers tends to increase with the altitude $(\mathrm{r}=0.61, \mathrm{p}$-value $=0.06)$. This suggests that most abundant species in the canopy still in more cases abundant in lower layers particularly at higher altitude plots. The species which do not follow this trend are those which are abundant in the canopy but become scarce in lower layers or they are abundant in lower layers and become scarce in the canopy (see species with p-values $\leq 0.05$ in the appendix).

\section{Correlation between light requirement and altitude in the three layers}

The variation of the light requirement (pioneer species, non-pioneer light demanding species: "NPLD" and shade tolerant species) is presented in the Table 2 to test if they are correlated to the altitude in the three layers. The aim in this computation is to assess if the number of pioneer species is negatively correlated to the altitude and the number of nonpioneer light demanding and shade tolerant species are positively correlated to the altitude. 
Table 2. Correlation between the number of individuals belonging to each light requirement $(L R)$ category within the three layers and the altitude. Bold p-values represent significant correlations at $\alpha=0.05$. The proportion of each LR category is represented in the \% column

\begin{tabular}{l|ccc|ccc|ccc}
\cline { 2 - 9 } & \multicolumn{3}{c|}{ Sapling layer } & \multicolumn{3}{c|}{ Understorey layer } & \multicolumn{3}{c}{ Canopy layer } \\
\hline \multicolumn{1}{c}{ Light requirement } & $\%$ & $r$ & $p$ & $\%$ & $r$ & $p$ & $\%$ & $r$ & $p$ \\
\hline Pioneer species & 6.3 & -0.72 & $\mathbf{0 . 0 2}$ & 16.3 & -0.7 & $\mathbf{0 . 0 3}$ & 21.8 & -0.67 & $\mathbf{0 . 0 3}$ \\
Non-pioneer light demanding species & 26.0 & 0.65 & $\mathbf{0 . 0 4}$ & 43.9 & 0.61 & 0.06 & 64.0 & 0.85 & $\mathbf{0 . 0 0 2}$ \\
Shade tolerant species & 41.4 & 0.63 & 0.05 & 33.6 & 0.35 & 0.32 & 13.3 & 0.03 & 0.93 \\
Unclassified species & 26.3 & -0.1 & 0.78 & 6.2 & 0.17 & 0.64 & 0.9 & 0.03 & 0.93 \\
\hline
\end{tabular}

In terms of individuals, non-pioneer light demanding species are more represented in the whole studied area $(40.8 \%)$ followed by shade tolerant species $(34.1 \%)$, pioneer species $(14.1 \%)$ and unclassified species $(11 \%)$, the Chi squared test showed a significant difference $\left(\chi^{2}=25.59, \mathrm{df}=3, \mathrm{p}<0.0001\right)$. The number of pioneer species generally decreases with the altitude this pattern being significant in the three layers. On contrary, the number of non-pioneer light demanding species and the number of shade tolerant species tend to increase with the altitude. This correlation is significant for the non-pioneer light demanding species in the sapling and the canopy layer.

\section{Discussion}

\section{The species richness and diversity of woody layers decrease with altitude}

In some montane forests, the species richness and diversity of woody plants begins to decrease above $1500 \mathrm{~m}$ a.s.l (Gentry, 1988). This decrease is due to multitude factors which vary with the altitude including the geomorphological factors, soil, humidity, cloudiness, temperature... (Delnatte, 2010; Malhi and Phillips, 2005). This pattern is also observed for non woody plants (Raman et al., 2005; Richter et al., 2009) even if the opposite trend (increasing species richness and diversity with altitude) can be observed, for example, in rattan communities in Indonesia (Siebert, 2005) and for the Melastomataceae family in French Guiana (Delnatte, 2010).

In the highland areas in the KBNP, species richness of plants and their diversity decreases with altitude for the Rubiaceae family (Mwanga Mwanga et al., 2014) and for ferns (Mangambu et al., 2013). We obtained the same result for the total woody floristic composition in the sapling, understorey and canopy layers. This confirms the findings of Imani et al. (2016) who found the same trend in a study conducted in the same ecosystem and in the surroundings of the Park in which they only considered tree species $\geq 10 \mathrm{~cm} \mathrm{DBH}$. The higher altitudes are characterized by a lower number of species and a lower diversity. Nevertheless, the number of individuals increases with the altitude, the same pattern was found by Gonmadje et al. (2011) in Cameroonian montane forests and Imani et al. (2016) in the KBNP and its surroundings.

\section{Forest stability in the Kahuzi-Biega National Park's highlands}

The dissimilarity between the canopy and understorey layer decreases with altitude

The canopy layer plots at higher altitudes are more similar to their understorey layer compared to the lower altitudes plots. The Jaccard index of dissimilarity decreases when 
the altitude increases. This encounters the statements of Bell (2000) for whom the composition of a community will be highly correlated with that of its immediate successor. Environmental-limitation conditions (lower temperatures, humidity, cloudiness...) created by the altitude act as ecological filtering and inhibit the installation of some species at higher altitudes (Salas-Morales and Meave, 2012). Only some plant species succeed to live in such conditions. This is the reason why the floristic difference between layers diminishes with increasing altitude as many species present in the canopy layer are encountered also in the understorey layers at those altitudes. McEwan et al. (2005) found in the case of their study in an old-growth forest of Kentucky in the USA that layers similarity increases with altitude. Wu et al. (2007) found the same results in the Mount Fuji in Japan.

\section{Variation of the relative abundance of canopy species}

After past disturbances in the highlands of the KBNP (Masumbuko, 2011; Kabonyi et al., 2011), the regeneration capabilities of canopy species were less known. The results from this study showed that the most represented species in the canopy are also well represented in the lower layers at higher altitudes (see Figure 4). Gonzalez et al. 2010 found that the relative abundance of a given species in two compared layers can highlight some insights on its dynamics and the forest stability.

Successive layers such as sapling/understorey and understorey/canopy are not independent because each one is largely built from survivors and offspring of previous ones (Hall and Swaine, 1976; Bell, 2000). This represents the main interest of studying sapling and or understorey layers which are made of species which may constitute the canopy layer in next generations (Gonzalez et al., 2010). In a dry tropical forest of Costa Rica, Kalacska et al. (2004) found that there are some species which are present only in the early stage of development and are absent in the late stage. Some species can be present in all stages of development but with varying abundances. It has been argued that the appearance or disappearance of species in a given layer (or stage of development) is a great signal in its dynamic trend (McGill et al., 2007), either it is replacing or it is being replaced (McEwan et al., 2005; Zhang et al., 2009; Njunge and Mugo, 2011). Canopy species with high relative abundance in lower layers could maintain their presence in the canopy layer even in next generations (Hall and Swaine, 1976).

\section{Does the light requirement confirm the floristic stability of higher altitudes?}

The light requirement of species can be informative of the level of stability of a forest (Pierlot, 1966; Lovett et al., 2006). In the sylvigenetic cycle, early stage of development of a forest is dominated by trees which will be replaced by others, these trees are generally pioneer species (Hallé et al., 1978; Gourlet-Fleury et al., 2005). In the absence of high disturbance, pioneer species characterized by a short life span form a first canopy which constituent will be replaced by non-pioneer light demanding species and/or shade tolerant species which grow beneath this canopy (Whitmore, 1989; Van Gemerden et al., 2003b). When the forest tends to be stable it becomes more dominated by non-pioneer light demanding and shade tolerant species (Hall and Swaine, 1976; Whitmore, 1989; Van Gemerden et al., 2003b; Lovett et al., 2006). This affects the understorey and sapling's composition because of the lack of sunlight causing difficult germination and growth conditions to pioneer species (Harper 1977 in Reed and Foster, 1984). In the case 
of this study, we find that the number of pioneer species is lower than that of shade tolerant species and non-pioneer light demanding species.

The Table 2 showed that in all layers the number of pioneer species which are proof of large and recent disturbance (Van Gemerden et al., 2003b) are negatively correlated to the altitude and that non-pioneer light demanding species and shade tolerant species are positively correlated to the altitude. Plots situated at lower altitude are more disturbed than those at higher altitude suggesting that higher altitudes are more stable than lower. As said above, this could be a consequence of past and recurrent political turmoil which affected severely lower altitudes than higher ones.

\section{Conclusion}

Like herbaceous species and other organisms, woody plant species richness and diversity decrease with increasing altitude. Both sapling, understorey and canopy species showed this trend. Higher altitudes have low number of species and high number of individuals in the three layers. Plots situated at higher altitudes are more stable than those at lower altitudes. This was confirmed by the result from the Jaccard index of dissimilarity, the comparison of relative abundances and the variation of pioneer and non-pioneer species with the altitude. From the comparison of canopy and understorey or sapling abundances we can predict that the well represented canopy species in the understorey or in the sapling could form the future canopy as long as an equilibrium rate of mortality, regeneration and growth is maintained. Furthermore, we observed that pioneer species which are more abundant in unstable forests are more represented at lower altitudes than they are at higher and that non-pioneer and shade tolerant species increase with the altitude supporting the statements that high altitudes are more floristically stable than lower altitudes. In spite of these conclusions, we suggest that other studies can be conducted to clarify the role of other factors than altitude (geomorphological factors, soil, temperature, cloudiness, humidity, seed dispersal...) in the stability of montane forests.

Acknowledgements. This paper is one of findings of a $\mathrm{PhD}$ thesis research being conducted in the Kahuzi-Biega National Park (KBNP) thanks to financial supports from the European Union (EU) through the Center for International Forestry Research (CIFOR). We thank the University of Kisangani staff for their support and accompaniment. Thanks to our field guides and all researchers who helped us during data collection campaigns and analysis.

\section{REFERENCES}

[1] Admassu, A., Teshome, S., Ensermu, K., Abyot, D., Alemayhu, K. (2016): Floristic composition and plant community types of Agama Forest, an Afromontane Forest in Southwest Ethiopia. - Journal of Ecology and The Natural Environment 8(5): 55-69.

[2] Amani, I. A. C., Lejoly, J. (2014): Floristic patterns and impact of edaphic heterogeneity on species assemblages within woody forests layers in semi-deciduous forests from the Congo Basin. -Greener Journal of Agronomy, Forestry and Horticulture 2 (3): 062-072.

[3] Ashton, P. S., Hall, P. (1992): Comparisons of structure among mixed dipterocarp forests of north-western Borneo. - Journal of Ecology 80: 459-481.

[4] Behera, S. K., Misra, M. K. (2006): Floristic and structure of the herbaceous vegetation of four recovering forest stands in the Eastern Ghats of India. - Biodiversity and Conservation 15: 2263-2285. 
[5] Bell, G. (2000): The distribution of abundance in neutral communities. - The American Naturalist 155(5): 606-617.

[6] Bénédet, F., Doucet, J.-L., Fayolle, A., Gourlet-Fleury, S., Vincke, D. (2016, April): Cofortraits, African plant traits information database. Version 1.0. http://coforchange.cirad.fr/african_plant_trait

[7] Bussmann, R. W. (2001a): The montane forests of Reserva Biológica San Francisco (Zamora Chinchipe, Ecuador) - vegetation zonation and natural regeneration. - Die Erde 132: 11-24.

[8] Bussmann, R. W. (2001b): Epiphyte diversity in a tropical Andean forest Reserva Biológica San Francisco, Zamora-Chinchipe, Ecuador. - Ecotropica 7(1-2): 43-60.

[9] Chase, M. W., Christenhusz, M. J. M., Fay, M. F., Byng, J. W., Judd, W. S., Soltis, D. E., Mabberley, D. J., Sennikov, A. N., Soltis, P. S., Stevens, P .F. (2016): An update of the Angiosperm Phylogeny Group classification for the orders and families of flowering plants: APG IV. - Bot. J. Linn. Soc. 18

[10] Clinebell, R. R., Phillips, O. L., Gentry, A. H., Stark, N., Zuuring, H. (1995): Prediction of neotropical tree and liana species richness from soil and climatic data. - Biodiversity and Conservation 4: 56-90.

[11] Connell, J. H., Lowman, M. D. (1989): Low-diversity tropical rain forests: some possible mechanisms for their existence. - The American naturalist 134(1): 89-119.

[12] De Barcellos Falkenberg, D., Voltolini. J. C. (1995): The montane cloud forest in southern Brazil. Pp 138-149. - In: Hamilton, L. S., Juvik, J. O., Scatena, F. N. (eds.) Tropical Montane Cloud Forests. Springer-Verlag, New York.

[13] Delnatte C. (2010): Le gradient altitudinal sur les sommets tabulaires de Guyane, basé sur l'étude des Arecaceae, des Melastomataceae et des Ptéridophytes. - Thesis submitted to the Université des Antilles-Guyane.

[14] Dimitrov, D., Nogués-Bravo, D., Scharff, N. (2012): Why do tropical mountains support exceptionally high biodiversity? The eastern arc mountains and the drivers of Saintpaulia diversity. - PLoS ONE 7(11): 1-15.

[15] Doumenge, C. (1998): Forest diversity, distribution, and dynamique in the Itombwe Mountains, South-Kivu, Congo Democratic Republic. - Mountain Research and Development 18(3): 249-264.

[16] Dupuy, B. (1998): Bases pour une sylviculture en forêt dense tropicale humide africaine. - Série FORAFRI Document 4, CIRAD-Forêt.

[17] Dupuy, B., De Madron, L. D., Petrucci, Y. (1998): Sylviculture des peupleuments naturels en forêt dense humide Africaine: Acquis et recommandations. - Bois et forêts des tropiques 257(3): 5-22.

[18] Fine, P. V. A., Daly, D. C., Muñoz, G. V., Mesones, I., Cameron, K. M. (2005): The contribution of edaphic heterogeneity to the evolution and diversity of Burseraceae trees in the western Amazon. - Evolution 59(7): 1464-1478.

[19] Fischer, E. (1993): La végétation du Parc National de Kahuzi-Biega (Sud-kivu/Zaïre). Botanisches Institut und Botanischer Garten der, Bonn.

[20] Fischer, E., Killmann, D. (2008): Illustrated field guide to the plants of Nyungwe National Park, Rwanda. - Koblenz Geographical Colloquia, Series Biogeographical Monographs 1.

[21] Fisher, R. A., Corbet, A. S., Williams, C. B. (1943): The relation between the number of species and the number of individuals in a random sample of an animal population. $-\mathrm{J}$. Anim. Ecol. 12: 42-58.

[22] Fjeldså, J., Lovett, J. C. (1997): Biodiversity and environmental stability. - Biodiversity and Conservation 6: 315-323.

[23] Gentry, A. H. (1988): Changes in plant community diversity and floristic composition on environmental and geographical gradients. - Ann. Missouri Bot. Gard. 75: 1-34. 
[24] Gonmadje, C. F. (2012): Diversité et biogéographie des forêts d'Afrique atlantique: le cas du massif de Ngovayang (Cameroun). - Thesis submitted to the Université de Montpellier II, France.

[25] Gonmadje, C. F., Doumenge, C., Mckey, D., Tchouto, P. M., Sunderland, C. H., Balinga, P. B., Sonké, B. (2011): Tree diversity and conservation value of Ngovayang's lowland forests, Cameroon. - Biodivers. Conserv. 20: 2627-2648.

[26] Gonmadje, C., Picard, N., Gourlet-Fleury, S., Réjou-Méchain, M., Freycon, V., Sunderland, T., Mckey, D., Doumenge, C. (2017): Altitudinal filtering of large-tree species explains above-ground biomass variation in an Atlantic Central African rain forest. - Journal of Tropical Ecology 33(02): 143-154.

[27] González, G., Willig, M. R., Waide, R. B. (2013): Ecological gradient analyses in a tropical landscape: multiple perspectives and emerging themes. - Ecological Bulletins 54: 13-20.

[28] Gonzalez, M. A., Roger, A. Courtois, E. A., Jabot, F., Norden, N., Paine, C. E. T., Baraloto, C., Thebaud, C., Chave, J. (2010): Shifts in species and phylogenetic diversity between sapling and tree communities indicate negative density dependence in a lowland rain forest. - Journal of Ecology 98: 137-146.

[29] Goslee, S. C., Urban, D. L. (2007): The ecodist package for dissimilarity-based analysis of ecological data. - Journal of Statistical Software 22(7): 1-19.

[30] Gourlet-Fleury, S., Blanc, L., Picard, N., Sist, P., Dick, J,. Nasi, R., Swaine, M. D., Forni, E. (2005): Grouping species for predicting mixed tropical forest dynamics: looking for a strategy. - Annals of Forest Science 62(8): 785-796.

[31] Gourlet-Fleury, S., Beina, D., Fayolle, A., Ouédraogo, D.-Y., Mortier, F., Bénédet, F., Closset-Kopp, D., Decocq, D. (2013): Silvicultural disturbance has little impact on tree species diversity in a Central African moist forest. - Forest Ecology and Management 304: 322-332.

[32] Hall, J. B., Swaine, M. D. (1976): Classification and ecology of closed-canopy forest in Ghana. - The Journal of Ecology 64(3): 913-951

[33] Hallé, F., Oldeman, R. A. A., Tomlinson, P. B. (1978): Tropical Trees and Forests. Berlin, Heidelberg: Springer Berlin Heidelberg.

[34] Hawthorne, W. (1996): Holes and the sums of parts in Ghanaian forest: regeneration, scale and sustainable use. Proceedings of the Royal Society of Edinburgh. Section B. Biological Sciences 104: 75-176.

[35] Hedberg, O. (1951): Vegetation belts of the East African mountains. - Svensk Botanisk Tidskrift 45: 140-202.

[36] Hemp, A. (2006): Continuum or zonation? Altitudinal gradients in the forest vegetation of Mt. Kilimanjaro. - Plant Ecology 184(1): 27-42.

http://digitalcommons.macalester.edu/biogeography/vol1/iss1/3 https://doi.org/10.1017/S0266467416000602

[37] Hurlbert, S. H. (1971): The nonconcept of species diversity: a critique and alternative parameters. - Ecology 52: 577-586.

[38] Imani, G., Zapfack, L., Kalume, J., Riera, B., Cirimwami, L., Boyemba, F. (2016): Woody vegetation groups and diversity along the altitudinal gradient in mountain forest: case study of Kahuzi-Biega National Park and its surroundings, RD Congo. - Journal of Biodiversity and Environmental Sciences 8(6): 134-150.

[39] Jaccard, P. (1908): Nouvelles recherches sur la distribution florale. - Bull. Soc. Vaudoise Sci. Nat. 44: 223-270.

[40] Jamir, S. A., Upadhaya, K., Pandey, H. N. (2006): Life form composition and stratification of montane humid forests in Meghalaya, northeast India. - Tropical Ecology 47(2): 183-190. 
[41] Jepson, P., Caldecott, B., Milligan, H., Chen, D. (2015): A framework for protected area asset management. - Smith school of the enterprise and the environment. Oxford, United Kingdom.

[42] Kabonyi, C., Salmon, M., Roche, E. (2011): Le Parc National de Kahuzi-Biega (R. D. Congo), patrimoine en péril? Le secteur « Haute Altitude », situation et perspectives. Geo-Eco-Trop. 35: 1-8.

[43] Kalacska, M., Sanchez-Azofeifa, G. A., Calvo-Alvarado, J. C., Quesada, M., Rivard, B., Janzen, D. H. (2004): Species composition, similarity and diversity in three successional stages of a seasonally dry tropical forest. - Forest Ecology and Management 200(1-3): 227247.

[44] Körner, C. (2009): Mountain Vegetation under Environmental Change. - In: Jandl, R., Borsdorf, A., van Miegroet, H., Lackner, R., Psenner, R. (eds.) Alpine space-man \& environment, vol. 7: Global Change and Sustainable Development in Mountain Regions. 7: 25-30.

[45] Lebrun, J. P., Stork, A. L. (1991-2015): Enumération des plantes à fleurs d'Afrique tropicale et Tropical African Flowering Plants. - Ecology and Distribution (1991-2015) 1: 7.

[46] Lebrun, J., Gilbert, G. (1954): Une classification écologique des forêts du Congo. Publications INEAC; Série Sciences. $\mathrm{N}^{\circ} 63$.

[47] Legendre, P., Borcard, D., Peres-Neto, P. R. (2005): Analyzing beta diversity: partitioning the spatial variation of community composition data. Concepts and Synthesis. - Ecological Monographs 1-25.

[48] Lenoir, J. (2009): Impacts d'un réchauffement rapide du climat sur la distribution des espèces végétales forestières le long du gradient d'altitude. - Thesis submitted to the AgroParisTech.

[49] Letouzey, R. (1957): La forêt à Lophira alata de la zone littorale Camerounaise. - Bois et forêts des tropiques 53: 9-20.

[50] Lomolino, M. V. (2001): Elevation gradients of species-density: historical and prospective views. - Global Ecology and Biogeography 10: 3-13.

[51] Lovett, J. C., Ruffo, C. K., Gereau, R. E., Taplin, J. R. (2006): Field guide to the moist forest trees of Tanzania. - Society for Environmental Exploration: 192. http://www.cepf.net/Documents/Final_LovettRuffoGereau_FieldGuide.pdf

[52] Magrath, W. B. (2007): Timber theft prevention: introduction to security for forest managers. - World Bank.

[53] Magurran, A. E. (2004): Measuring biological diversity. - Malden, Ma: Blackwell Pub.

[54] Malhi, Y., Phillips, O. (eds.) (2005): Tropical forests and global atmospheric change. Oxford; New York: Oxford University Press.

[55] Mangambu, J. D. M., Wabika, D. P., Imani, M. G., Mwanga Mwanga, I. J.-C. (2013): Etude préliminaire sur la connaissance taxonomique et endémisme des Rubiaceae du parc national de Kahuzi-Biega à l'est de la R.D Congo. - Continental J. Biological Sciences 6(3): $33-42$.

[56] Mangambu, M. (2013): Taxonomie, biogéographie et écologie des ptéridophytes de l'écosystème forestier des montagnes du Parc National de Kahuzi-Biega à l'Est de la R.D. Congo. - Thesis submitted to the Université d'Anvers, Belgique.

[57] Masumbuko, N. C. (2011): Ecologie de Sericostachys scandens, liane envahissante dans les forêts de Montagne du Parc National de Kahuzi-Biega, République Démocratique du Congo. - Thèse de doctorat, Faculté des Sciences, Laboratoire d'Ecologie végétale et Biogéochimie. Université Libre de Bruxelles, 176.

[58] Mccain, C. M., Grytnes, J.-A. (2010): Elevational gradients in species richness. - In: John Wiley and Sons (eds.), Encyclopedia of Life Sciences. Chichester, UK: John Wiley \& Sons, Ltd. 
[59] Mcewan, R. W., Muller, R. N., Mccarthy, B. C. (2005): Vegetation-environment relationships among woody species in four canopy-layers in an old-growth mixed mesophytic forest. - Castanea 70(1): 32-46.

[60] Mcgill, B. J., Etienne, R. S., Gray, J. S., Alonso, D., Anderson, M. J., Benecha, H. K., Dornelas, M., Enquist, B. J., Green, J. L., He, F., Magurran, A. E., Marquet, P. A., Maurer, B. A., Ostling, A., Soykan, C. U., Ugland, K. I., White, E. P. (2007): Species abundance distributions: moving beyond single prediction theories to integration within an ecological framework. - Ecology Letters 10(10): 995-1015.

[61] Mwanga Mwanga, I. J.-C., Wabika, D., Imani, M., Balezi, Z. (2014): Distribution altitudinale des Rubiaceae dans les forêts de montagnes à l'est de la R.D. Congo. Cas du Parc national de Kahuzi-Biega et de la forêt communautaire de Rwaga-Nirindja. Continental J. Applied Sciences 9(2): 1-9.

[62] Nicotra, A. B., Chazdon, R. L., Iriarte, S. V. (1999): Spatial heterogeneity of light and woody seedling regeneration in tropical wet forests. - Ecology 80(6): 1908-1926.

[63] Njunge J. T., Mugo, J. M. (2011): Composition and succession of the woody flora of the South Nandi Forest, Kenya. - Research Journal of Botany 6(3): 112-121.

[64] Nzigidahera, B. (2012): Vulnérabilité des forêts ombrophiles de montagne aux changements climatiques au Burundi: Renforcement de leur pouvoir d'adaptation. - Bull. sci. Inst. Natl. Environ. Conserv. Nat. 10: 35-45.

[65] Oksanen, J., Blanchet, G. F., Friendly, M., Kindt, R., Legendre, P., McGlinn, D., Minchin, P. R., O'Hara, R. B., Simpson, G. L., Solymos, P., Stevens, M. H. H., Szoecs, E., Wagner, H. (2017): Vegan: Community Ecology Package. R package version 2.4-3. https://CRAN.R-project.org/package=vegan

[66] Pierlot, R. (1966): Structure et composition de forêts denses d'Afrique Centrale, spécialement celles du Kivu. 1966. - Académie royale de Bruxelles, Belgique.

[67] Pivellon, V. R., Coutinho, L. M. (1996): A qualitative successional model to assist in the management of Brazilian cerrados. - Forest Ecology and Management 87: 127-138.

[68] Plumptre, A. J., Davenport, T. R. B., Behangana, M., Kityo, R., Eilu, G., Ssegawa, P., Ewango, C., Meirte, D., Kahindo, C., Herremans, M., Peterhans, J. K., Pilgrim, J. D., Wilson, M., Languy, M., Moyer, D. (2006): The biodiversity of the Albertine Rift. Biological Conservation 134(2): 178-194. https://doi.org/10.1016/j.biocon.2006.08.021

[69] Poulsen, A. D., Hafashimana, D., Eilu, G., Liengola, I. B., Ewango, C. E. N., Hart, T. B. (2005): Composition and species richness of forest plants along the Albertine Rift, Africa. - Biol. Skr. 55: 129-143.

[70] Raman, T. R., Joshi, N. V., Sukumar, R. (2005): Tropical rainforest bird community structure in relation to altitude, tree species composition, and null models in the Western Ghats, India. - arXiv preprint q-bio/0510033.

[71] Reed, D. C., Foster, M. S. (1984): The Effects of Canopy Shadings on Algal Recruitment and Growth in a Giant Kelp Forest. - Ecology 65(3): 937-948.

[72] Richter, M., Diertl, K.-H., Emck, P., Peters, T., Beck, E. (2009): Reasons for an outstanding plant diversity in the tropical Andes of Southern Ecuador. - Landscape Online 12: 1-35.

[73] Runge, J. (2007): Des déserts et des forêts, histoire du paysage et du climat de l'Afrique Centrale au Quaternaire Supérieur. - Geo-Eco-Trop. 31: 1-18.

[74] Salas-Morales, S. H., Meave, J. A. (2012): Elevational patterns in the vascular flora of a highly diverse region in southern Mexico. - Plant Ecology 213(8): 1209-1220.

[75] Schmitt, C. B., Denich, M., Demissew, S., Friis, I., Juerg, H. (2010): Floristic diversity in fragmented Afromontane rainforests: Altitudinal variation and conservation importance. Applied Vegetation Science 13: 291-304.

[76] Schulze, E.-D., Beck, E., Müller-Hohenstein, K. (2005): Plant ecology. - Berlin: Springer. 
[77] Sharma, E., Chettri, N., Tse-Ring, K., Shrestha, A. B., Jing, F., Mool, P., Eriksson, M. (2009): Climate change impacts and vulnerability in the Eastern Himalayas. Kathmandu: ICIMOD.

[78] Shiels, A. B., Walker, L. R. (2013): Landslides cause spatial and temporal gradients at multiple scales in the Luquillo Mountains of Puerto Rico. - Ecological Bulletins 54: 211-221.

[79] Siebert, S. F. (2005): The abundance and distribution of rattan over an elevation gradient in Sulawesi, Indonesia. - Forest Ecology and Management 210: 143-158.

[80] Skarbek, C (2008): A Review of Endemic Species in the Eastern Arc Afromontane Region: Importance, Inferences, and Conservation. - Macalester Reviews in Biogeography: Vol. 1, Article 3.

[81] Swaine, M. D., Hall, J. B. (1988): The Mosaic theory of Forest Regeneration and the Determination of Forest Composition in Ghana. - Journal of Tropical Ecology 4(3): 253-269.

[82] Tassin, J., Derroire, G., Rivière, J.-N. (2004): Gradient altitudinal de la richesse spécifique et de l'endémicité de la flore ligneuse indigène à l'Ile de la Réunion (archipel de Mascareignes). - Acta Bot. Gallica 151(2): 181-196.

[83] Troupin, G., Bridson, D. M. (1982): Flore des plantes ligneuses du Rwanda. Musée Royal de l'Afrique Centrale - Tervuren, Belgique Annales-Serie In- $8^{\circ}$ - Sciences Economiques - $\mathrm{N}^{\circ} 12$.

[84] Tuomisto, H., Ruokolainen, K., (2006): Analyzing or explaining beta diversity? Understanding the targets of different methods of analysis. - Ecology 87: 2697-2708.

[85] Van Gemerden, B. S., Olff, H., Parren, M. P., Bongers, F. (2003b): The pristine rain forest? Remnants of historical human impacts on current tree species composition and diversity. - Journal of Biogeography 30: 1381-1390.

[86] Van Gemerden, B. S., Shu, G. N., Olff, H. (2003a): Recovery of conservation values in Central African rain forest after logging and shifting cultivation. - Biodiversity \& Conservation 12(8): 1553-1570.

[87] Vandermeer, J., Granzow de la Cerda, I. (2004): Height dynamics of the thinning canopy of a tropical rain forest: 14 years of succession in a post-hurricane forest in Nicaragua. Forest Ecology and Management 199(1): 125-135.

[88] White, F. (1983): The vegetation of Africa. A descriptive Memoire to Accompany the UNESCO/AETFAT Vegetation Map of Africa. - UNESCO, Paris, UNESCO/AETFAT.

[89] Whitmore, T. C. (1989): Canopy gaps and the two major groups of the forest trees. Ecology 70(3): 536-538.

[90] Woods, K. D., Whittaker, R. H. (1981): Canopy-understory interaction and the internal dynamics of mature hardwood and Hemlock-Hardwood forests. - In: Reichle, D. E. (ed.) Forest succession: concepts and application. Heidelberg, Berlin. 305-323.

[91] World Heritage (2005): World Heritage at the $V^{\text {th }}$ IUCN. - World Parks Congress Durban (South Africa), 8-17 September 2003.

[92] Wu, B., Hogetsu, T., Isobe, K., Ishii, R. (2007): Community structure of arbuscular mycorrhizal fungi in a primary successional volcanic desert on the southeast slope of Mount Fuji. - Mycorrhiza 17(6): 495-506.

[93] Yang, K.-C., Lin, J.-K., Hsieh, C.-F., Huang, C.-L., Chang, Y.-M., Kuan, L.-H., Su, J.-F., Chiu, S.-T. (2008): Vegetation pattern and woody species composition of a broad-leaved forest at the upstream basin of Nantzuhsienhsi in mid-southern Taiwan. - Taiwania 53: 325-337.

[94] Zhang, J., Hao, Z., Sun, I.-F., Song, B., Ye, J., Li, B., Wang, X. (2009): Density dependence on tree survival in an old-growth temperate forest in northeastern China. Annals of Forest Science 66(2): 204-204.

[95] Zhang, J., Zhang, F. (2007): Diversity and composition of plant functional groups in mountain forests of the Lishan Nature Reserve, North China. - Botanical Studies 48: 339348. 